\title{
Reciprocal Garden Study Reveals Acute Spatial-Edaphic Adaptation for Cycas micronesica
}

\author{
Thomas E. Marler
}

check for

updates

Citation: Marler, T.E. Reciprocal Garden Study Reveals Acute Spatial-Edaphic Adaptation for Cycas micronesica. Diversity 2021, 13, 237. https://doi.org/10.3390/d13060237

Academic Editor: Michael Wink

Received: 28 April 2021

Accepted: 28 May 2021

Published: 29 May 2021

Publisher's Note: MDPI stays neutral with regard to jurisdictional claims in published maps and institutional affiliations.

Copyright: (C) 2021 by the author. Licensee MDPI, Basel, Switzerland. This article is an open access article distributed under the terms and conditions of the Creative Commons Attribution (CC BY) license (https:/ / creativecommons.org/licenses/by/ $4.0 /)$.
Western Pacific Tropical Research Center, University of Guam, UOG Station, Mangilao, Guam 96923, USA marler.uog@gmail.com

\begin{abstract}
A long-term reciprocal garden study was used to determine adaptive variation between Cycas micronesica K.D. Hill plants from north versus south Guam. Half-siblings from each location were planted as one-leaf seedlings in north and south gardens and monitored for 15 years. Stem height and diameter, and leaf number and maximum length were measured yearly. Survival and plant size traits were evaluated using a two-way factorial. In both locations, the local genotypes outperformed the foreign genotypes in terms of survival and growth. Survival of the foreign genotypes began to decline by year 4 and was less than $10 \%$ by year 15 . Survival of the local genotypes was $70 \%$ for the north garden and $100 \%$ for the south garden. The north site was more hostile to plant performance because overall survival and plant growth were less than for the south site. The most likely environmental factor provoking local adaptation was highly contrasting soil characteristics between north and south Guam. The results indicates that long-term conservation success for C. micronesica and other cycad species must include the concept of local adaptation into decisions for transplantation and restoration projects.
\end{abstract}

Keywords: cycad; genetic diversity; natural selection; reciprocal transplant study

\section{Introduction}

Conservation of threatened plant species often includes the use of ex situ botanic garden germplasm curation [1-3] and translocations or reintroductions into restoration sites [4,5]. Botanic garden managers use horticultural protocols to sustain health and increase longevity of germplasm. Contrarily, after initial establishment of transplanted germplasm into restoration sites the goal is for the plant population to become selfregenerating such that long-term management is not needed. Therefore, knowledge of the ecological needs of the plant species is required to avoid selection of inappropriate restoration sites or plant genotypes for prescribed sites [6].

Selection of local genotypes of plant species for use in restoration sites is often the safest approach to ensure adaptation of the plant material $[7,8]$. One way to move beyond this default approach is to conduct reciprocal garden studies which carry the potential to define adaptive variation in the plant populations among the natural areas of occupancy [9]. Reciprocal transplant experimental approaches have been used for decades to decompose the variation of adaptation into genetic variation in combination with environmental variation $[10,11]$.

Cycads are among the most threatened plants worldwide [12,13]. The current understanding of taxonomic diversity indicates there are 120 described Cycadaceae taxa and 242 described Zamiaceae taxa [14]. Numerous ex situ cycad collections are curated by professionals with the requisite biology, taxonomy, and record-keeping skills. These germplasm collections contain the genetic reservoir to enable reintroductions of many cycad species to threatened native habitats. To my knowledge, only one reciprocal transplant study has been conducted for any cycad species [15], so this valuable approach for determining adaptive variation has not been exploited sufficiently for cycad conservation. 
Cycas micronesica is one of five cycad species native to the United States [16]. The native range in the western Pacific includes the United States Commonwealth of the Northern Mariana Islands, the United States Territory of Guam, the Federated States of Micronesia islands of Yap, and the Republic of Palau [17]. The extensive range and extremely dense historical areas of occupancy caused this gymnosperm tree to be the most abundant tree on Guam in 2002 [18]. But plant mortality following invasions of several non-native insects beginning $2003[19,20]$ prompted an Endangered status on the Red List of the International Union for Conservation of Nature in 2006 [21] and a Threatened status on the United States Endangered Species Act in 2015 [22].

This $C$. micronesica study was established as a reciprocal garden study using north Guam genotypes and south Guam genotypes. The species exhibits highly constrained gene flow such that genetic structure in northern populations is distinct from that in southern populations [23]. The primary objective of the study was to determine if $C$. micronesica from Guam exhibited local adaptation such that a home site advantage would be apparent over a $15 \mathrm{y}$ growth period. The secondary objective was to determine if the level of plasticity differed between the two populations such that long-term survival in the foreign site differed between the experimental plants obtained from the two areas of occupancy.

\section{Materials and Methods}

This long-term study was conducted on the island of Guam from 2004 until 2020. Climate is classified as Af on the Köppen-Geiger climate scale. Daily high temperatures range from $30{ }^{\circ} \mathrm{C}$ for January, February, and December to $32{ }^{\circ} \mathrm{C}$ for May and June. Daily low temperatures range from $24{ }^{\circ} \mathrm{C}$ for January, February, and March to $25^{\circ} \mathrm{C}$ for the remainder of the year. A distinction for rainy versus dry season is recognized, but rainfall can be substantial in any month of the year. Mean rainfall ranges from $42 \mathrm{~mm}$ for March to $296 \mathrm{~mm}$ for August, and is $1600 \mathrm{~mm}$ per year.

Cycas micronesica seeds were collected from habitats in the extreme northern and southern limits of the island of Guam in November 2004. A single highly productive female parent tree was selected from each habitat such that the resulting experimental plants from each habitat were half-siblings. The north Guam seed source was $1.1 \mathrm{~m}$ from northern extreme of the island at $91 \mathrm{~m}$ above sea level (masl). The south Guam seed source was $2.6 \mathrm{~km}$ from southern extreme of the island at 88 masl. The two sites were separated by $45 \mathrm{~km}$ on a latitudinal gradient. The soft integument tissue was removed from each seed, then all seeds were stored in shaded ambient conditions for embryo maturation.

The seeds were soaked in municipal water for $24 \mathrm{~h}$ on 9 May 2005 then were incubated under shaded ambient conditions within large plastic bags containing a $\approx 4 \mathrm{~cm}$ bed of perlite to initiate germination. As each seed germinated, it was removed from the incubation bag and planted in a medium of $50 \%$ sand and $50 \%$ perlite within a $2.6 \mathrm{~L}$ container. The medium was watered daily and the seedlings remained in the perlite for four months to establish a robust radicle and a single fully mature seed leaf. The radicles were $\approx 16 \mathrm{~cm}$ long at this stage (Figure 1a). 


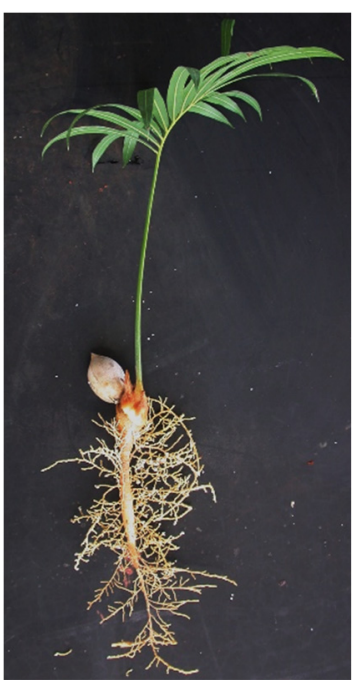

(a)

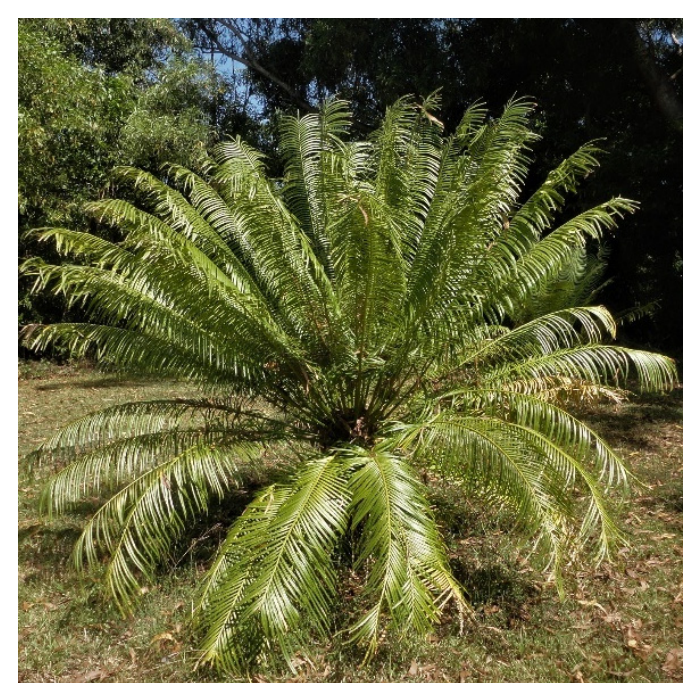

(b)

Figure 1. Cycas micronesica plants used in reciprocal garden study on Guam. (a) Four-month-old seedling used to establish the gardens; (b) Appearance of healthy local genotype after 15 years of growth.

The two garden sites were located within fenced agricultural experiment stations maintained by the University of Guam. The north garden site was located $12.5 \mathrm{~km}$ from the source tree, and was planted on 7 September 2005. The south garden site was located $1.4 \mathrm{~km}$ away from the source tree, and was planted on 14 September 2005.

Each seedling was carefully removed from the sand:perlite medium and planted without amending the field soil as bare-rooted seedlings. The plants were installed in a $2 \times 2 \mathrm{~m}^{2}$ grid within a border row, and each garden was positioned on the west side of a living wind break. The northern site windbreak was Casuarina equisetifolia L., and the southern site windbreak was Acacia auriculiformis A.Cunn. ex Benth. The gardens received filtered shade until midday, then full sun for most of the afternoon. The experimental layout was a randomized complete block with four blocks, each containing three plants per genotype.

Nitrogen-fixing cyanobacteria endosymbionts reside in specialized cycad root structures called coralloid roots [24]. My strict hygiene protocols used in handling the seeds, germination, and nursery seedling growth ensured no cyanobacteria from the source sites were transplanted with the seedlings to the experimental gardens. Moreover, the seedlings did not exhibit any visible coralloid roots when the gardens were installed. In order to ensure local cyanobacteria were available for all plants within each garden, coralloid roots were harvested from the seed source tree and several adjacent trees in October 2005, December 2005, and February 2006. The coralloid roots from each habitat were homogenized by pressing the combined tissue in a mortar and pestle and making a slurry by adding municipal water. Four 2-cm-deep holes were dug around the base of each plant by positioning the holes in cardinal directions. The holes were $5-\mathrm{cm}$ from the plant for the first application, $10-\mathrm{cm}$ from the plant for the second application, and $15-\mathrm{cm}$ from the plant for the third application. Only the local coralloid roots were applied in each garden, and $15 \mathrm{~mL}$ of the slurry was buried in each hole. Applying cyanobacteria or extracts from cyanobacteria to the base of plants is a common form of exploiting the benefits of cyanobacteria for plant health [25].

The north garden site consisted of shallow cobbly clay loams that formed in sediments that overlie coralline limestone (clayey, gibbsitic, nonacid, isohyperthermic, Lithic Ustorthents) [26]. Several plant micronutrients are limited in availability in this calcareous substrate because it is strongly alkaline. The south garden site consisted of a highly weathered volcanic soil that formed in residuum derived dominantly from tuff and tuff breccia (very fine, kaolinitic, isohyperthermic Oxic Haplustalfs) [26]. The strongly acid 
kaolinite clays have weathered over time to produce aluminum and iron oxides. Deficiency of calcium and toxicity of aluminum are common nutritional constraints for plants that grow in this soil series.

A site-specific soil analysis was conducted by collecting a $15 \mathrm{~cm}$ deep core from the four corners of each garden on the day of garden installation. Total carbon and nitrogen contents were determined by dry combustion (FLASH EA1112 CHN analyzer; Thermo Fisher, Waltham, MA, USA). Available phosphorus was determined by the Olsen method [27] for the alkaline soils and modified Truog method [28] for the acid soils. The remainder of extractable essential nutrients were quantified following digestion with diethylenetriaminepentaacetic acid [29]. Analysis was by inductively coupled plasma optical emission spectrometry (Spectro Genesis; SPECTRO Analytical Instruments, Kleve, Germany).

No horticultural inputs were provided, so the plants were forced to rely on the unamended native soil for all water and nutrient edaphic resources. Encroaching plants and insect herbivores were controlled with weekly scouting and interventions when necessary. The two ubiquitous non-native insect herbivores which required periodic control were the armored scale Aulacaspis yasumatsui Takagi and the specialist butterfly Luthrodes pandava Horsfield [19]. The scale was controlled with pyriproxyfen and the butterfly was controlled with dinotefuran. The history of $C$. micronesica evolution occurred in the absence of these two invasive insect herbivores and any other known leaf herbivore.

Survival and plant size measurements were conducted once per year until September 2020. Size metrics included stem height, basal stem diameter, leaf number, and maximum leaf length. All four of these variables increase dramatically as cycad plants develop from seedlings to juveniles because of the development of a large primary thickening meristem that enables height growth of the pachycaulous cycad stem [24]. The mean of each variable was calculated for each genotype within each block, then the data were subjected to analysis of variance with four blocks and a two-way factorial (Table 1).

Table 1. Experimental set-up for two-way factorial in each of two experimental sites in reciprocal transplant study.

\begin{tabular}{cc}
\hline Factor & Levels \\
\hline Genotype & Home versus Foreign \\
Year & $2005-2020$ \\
\hline
\end{tabular}

Year was designated as a repeated variable in the factorial (PROC MIXED, SAS Institute, Cary, NC, USA). For experimental approaches that contain a time-varying process, employing an autoregressive model is useful to account for the fact that the recurring variable partly depends on its own previous values. The predictive performance of autoregression is expected to improve as more data become available as the experiment progresses through time. An autoregressive covariance structure, unequal replications (which developed after plant mortality became extensive), and unequal variances were used in the model. Every variable exhibited a significant genotype $\times$ year interaction, and separation of genotype means for each garden within each year was conducted by the Mann-Whitney $U$ test [30] which does not require any assumption about distribution of the data. The analysis of variance was conducted separately for each of the gardens. The literature covering reciprocal garden studies includes the use of local, native, or home to describe plants from the vicinity of each garden. Plants from distant localities from each garden are often called nonlocal, foreign, or away. For this study, the two seed sources were designated as local and foreign transplants for each garden.

\section{Results}

\subsection{Soils}

The soils in the north Guam garden exhibited a pH of $8.01 \pm 0.04$, and contrasted sharply in elemental concentration from those in the south Guam garden, which exhibited 
a pH of $5.38 \pm 0.05$ (Table 2). Calcium, carbon, nitrogen, and phosphorus concentrations were greater in the north garden soil, the remainder of measured elements were greater in concentration in the south garden soil.

Table 2. The concentration of plant nutrients in soils from north and south Guam gardens used to grow Cycas micronesica plants. Mean \pm standard error, $n=4$.

\begin{tabular}{ccc}
\hline Nutrient & North Garden & South Garden \\
\hline Calcium & $6.56 \pm 0.06 \mathrm{mg} \cdot \mathrm{g}^{-1}$ & $0.72 \pm 0.05 \mathrm{mg} \cdot \mathrm{g}^{-1}$ \\
Carbon & $17.22 \pm 0.65 \mathrm{mg} \cdot \mathrm{g}^{-1}$ & $2.19 \pm 0.63 \mathrm{mg} \cdot \mathrm{g}^{-1}$ \\
Copper & $1.09 \pm 0.04 \mu \mathrm{g} \cdot \mathrm{g}^{-1}$ & $1.77 \pm 0.03 \mu \mathrm{g} \cdot \mathrm{g}^{-1}$ \\
Iron & $12.73 \pm 1.13 \mu \mathrm{g} \cdot \mathrm{g}^{-1}$ & $28.25 \pm 2.66 \mu \mathrm{g} \cdot \mathrm{g}^{-1}$ \\
Magnesium & $102.25 \pm 1.38 \mu \mathrm{g} \cdot \mathrm{g}^{-1}$ & $267.25 \pm 8.98 \mu \mathrm{g} \cdot \mathrm{g}^{-1}$ \\
Manganese & $5.11 \pm 0.15 \mu \mathrm{g} \cdot \mathrm{g}^{-1}$ & $7.63 \pm 0.21 \mu \mathrm{g} \cdot \mathrm{g}^{-1}$ \\
Nitrogen & $0.93 \pm 0.06 \mathrm{mg} \cdot \mathrm{g}^{-1}$ & $0.68 \pm 0.11 \mathrm{mg} \cdot \mathrm{g}^{-1}$ \\
Phosphorus & $42.25 \pm 1.38 \mu \mathrm{g} \cdot \mathrm{g}^{-1}$ & $6.03 \pm 0.11 \mu \mathrm{g} \cdot \mathrm{g}^{-1}$ \\
Potassium & $16.63 \pm 0.55 \mu \mathrm{g} \cdot \mathrm{g}^{-1}$ & $38.75 \pm 4.84 \mu \mathrm{g} \cdot \mathrm{g}^{-1}$ \\
Zinc & $1.37 \pm 0.22 \mu \mathrm{g} \cdot \mathrm{g}^{-1}$ & $1.91 \pm 0.16 \mu \mathrm{g} \cdot \mathrm{g}^{-1}$ \\
\hline
\end{tabular}

\subsection{Survival}

The southern Guam garden exhibited differences in survival for the genotypes and years. The genotype, year, and genotype $\times$ year interaction were all significant $(p \leq 0.001)$. Mortality of the foreign genotypes was extensive and by 2009 the survival was significantly less than that of the local genotypes (Figure 2a). Mortality of foreign genotypes was sustained until 2017 when mortality exceeded $90 \%$. In contrast, the local genotypes exhibited $100 \%$ survival following $15 \mathrm{y}$ of growth.

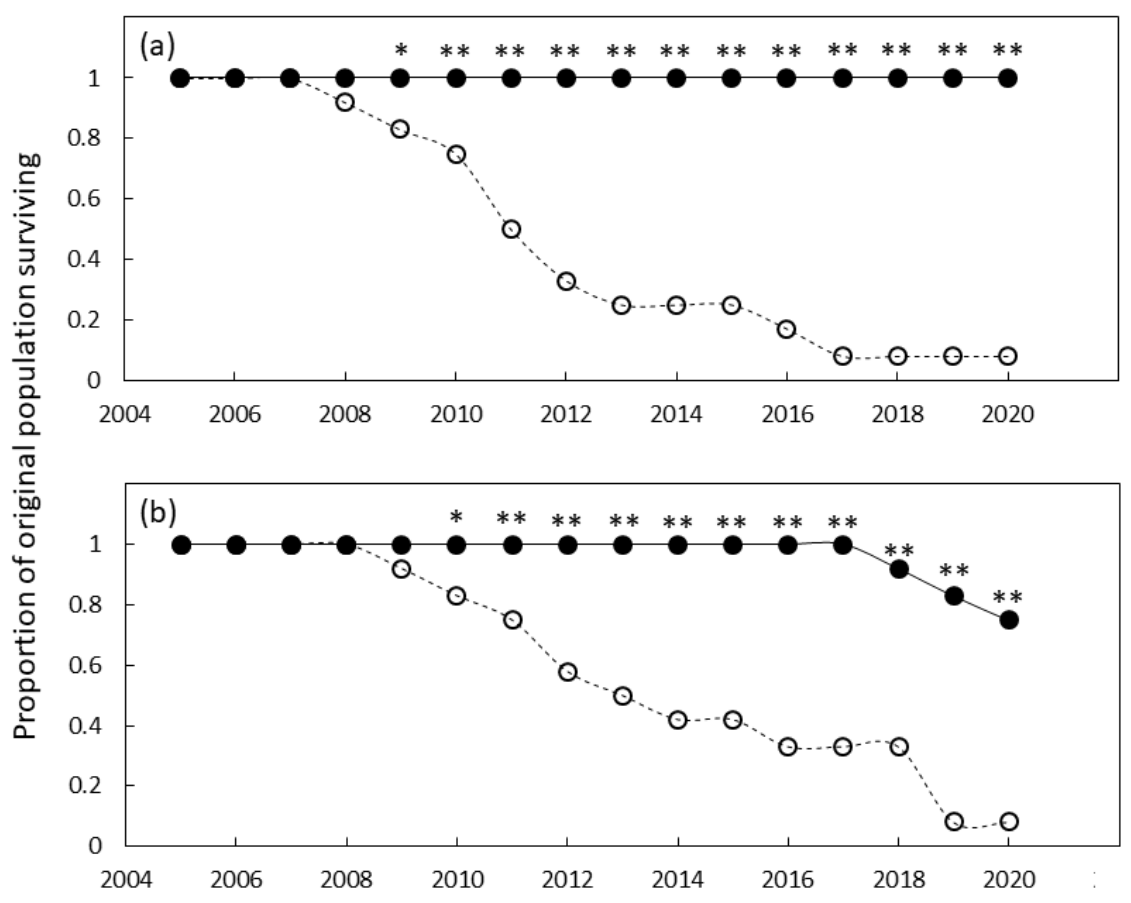

Figure 2. The proportion of original Cycas micronesica plants remaining alive over a 15 y growth period in (a) south Guam garden and (b) north Guam garden. Closed circles are local genotypes, open circles are foreign genotypes. ${ }^{*}=$ significant at $p \leq 0.05,{ }^{* *}=$ significant at $p \leq 0.01$.

The northern Guam garden exhibited similar results. The genotype, year, and genotype $\times$ year interaction were all significant $(p \leq 0.001)$. Mortality of the foreign genotypes was extensive and by 2010 the survival was significantly less than that of the home genotypes (Figure 2b). Mortality of foreign genotypes was sustained until 2019 when mortality 
exceeded $90 \%$. The local genotypes exhibited $100 \%$ survival until 2017, then survival declined to $\approx 70 \%$ by the end of the study.

The garden $\times$ genotype relationship is better understood when both garden locations are shown in a single figure (Figure 3). The poor performance and survival of foreign genotypes were similar in both garden locations, with more than $90 \%$ mortality. In contrast, the survival of local genotypes was dissimilar with the south garden out-performing the north garden.

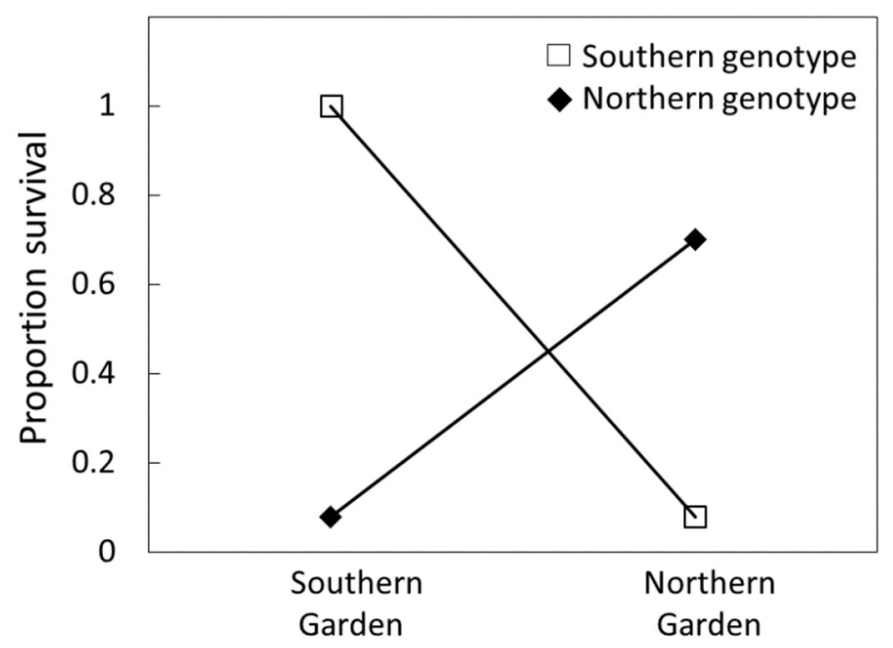

Figure 3. The proportion of original Cycas micronesica plants remaining alive over a 15 y growth period in two reciprocal garden locations in Guam. Open boxes represent southern Guam genotype, closed diamonds represent northern Guam genotypes.

\subsection{Plant Growth}

The south Guam garden plants were similar in size until 2011 when local genotypes were greater in stem diameter than foreign genotypes and 2012 when local genotypes were greater in height than foreign genotypes (Figure 4). By the end of the study, the local genotypes were $29 \%$ greater in stem diameter and $180 \%$ greater in stem height than the foreign genotypes. Leaf traits exhibited a similar pattern with local genotypes having greater leaf length by 2010 and greater leaf number by 2012 (Figure 5). By 2020 the local genotypes were $82 \%$ greater in leaf length and $222 \%$ greater in leaf number per plant than the foreign genotypes. The local genotypes exhibited robust appearance throughout the study (Figure 1b).

The north Guam garden plants were similar in size until 2019 when local genotypes were greater in stem diameter and height than foreign genotypes (Figure 6). By the end of the study, the local genotypes were $55 \%$ greater in stem diameter and $63 \%$ greater in height than the foreign genotypes. Leaf traits exhibited a similar pattern with local genotypes having greater leaf length and greater leaf number by 2019 (Figure 7). By 2020 the local genotypes were $37 \%$ greater in leaf length and $425 \%$ greater in leaf number per plant than the foreign genotypes. 

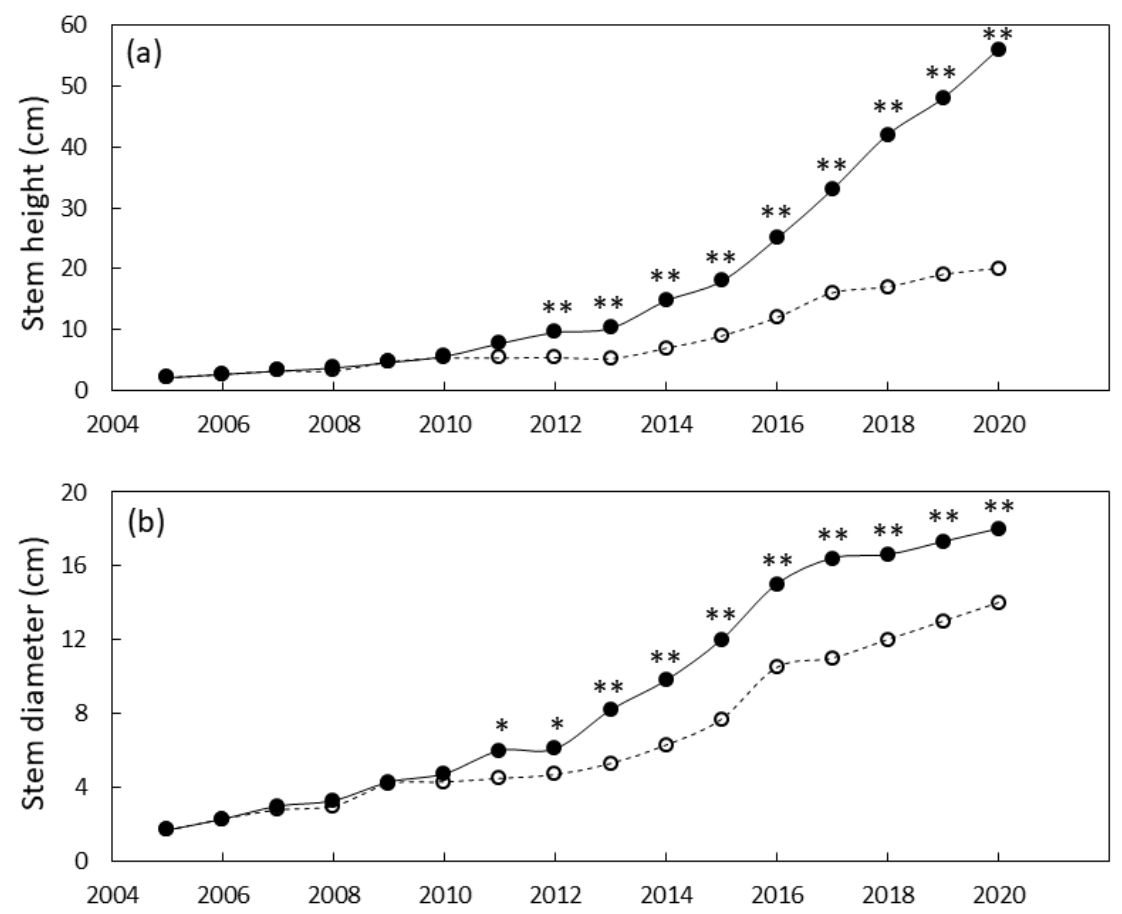

Figure 4. Size of Cycas micronesica plants growing in a south Guam garden over a $15 \mathrm{y}$ growth period. (a) stem height and (b) basal stem diameter. Closed circles are local genotypes, open circles are foreign genotypes. ${ }^{*}=$ significant at $p \leq 0.05,{ }^{* *}=$ significant at $p \leq 0.01$.
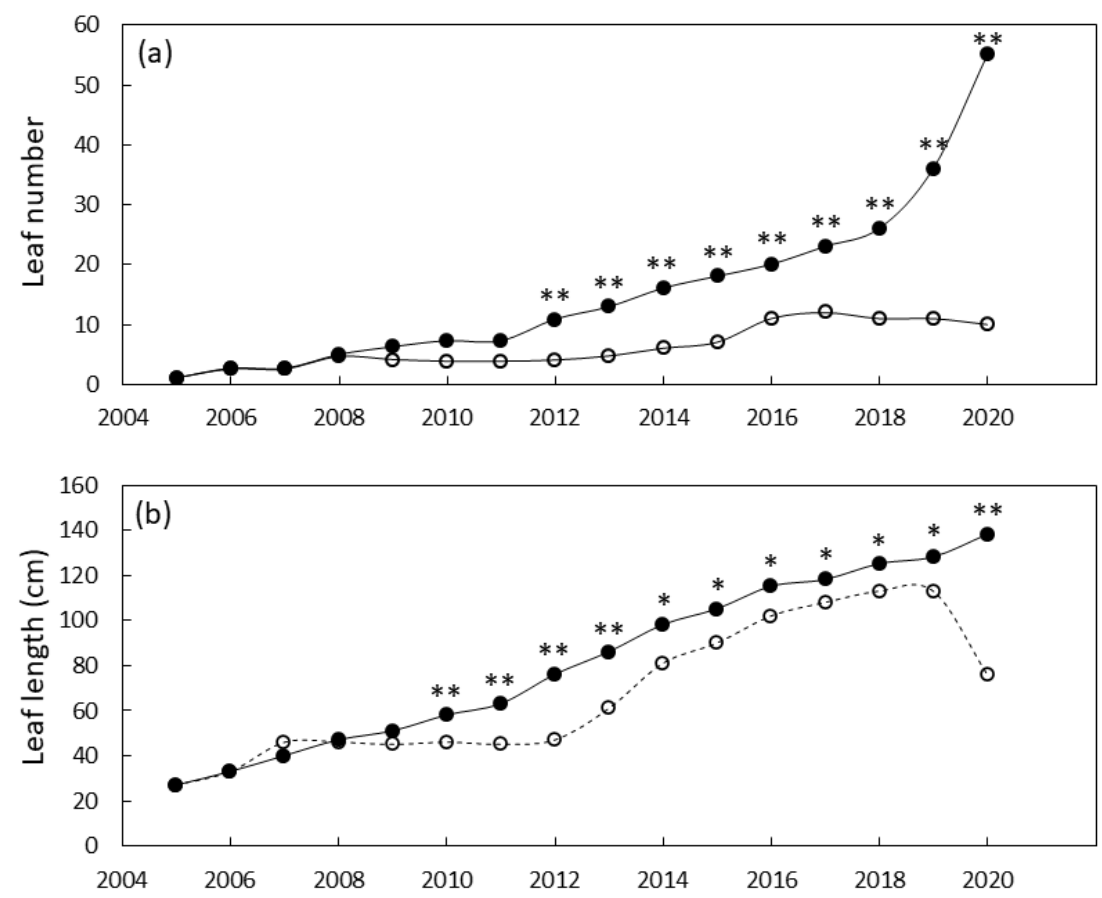

Figure 5. Size of Cycas micronesica plants growing in a south Guam garden over a $15 \mathrm{y}$ growth period. (a) leaf number and (b) maximum leaf length. Closed circles are local genotypes, open circles are foreign genotypes. ${ }^{*}=$ significant at $p \leq 0.05,{ }^{* *}=$ significant at $p \leq 0.01$. 

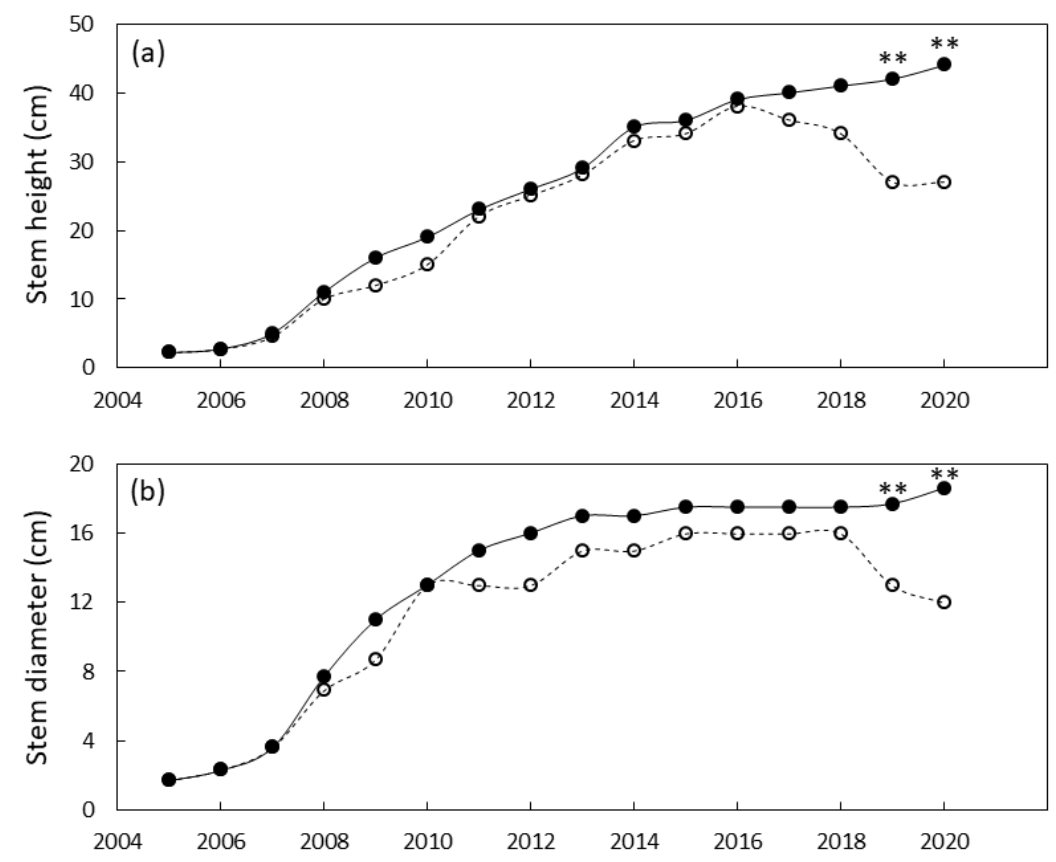

Figure 6. Size of Cycas micronesica plants growing in a north Guam garden over a $15 \mathrm{y}$ growth period. (a) stem height and (b) basal stem diameter. Closed circles are local genotypes, open circles are foreign genotypes. ${ }^{* *}=$ significant at $p \leq 0.01$.
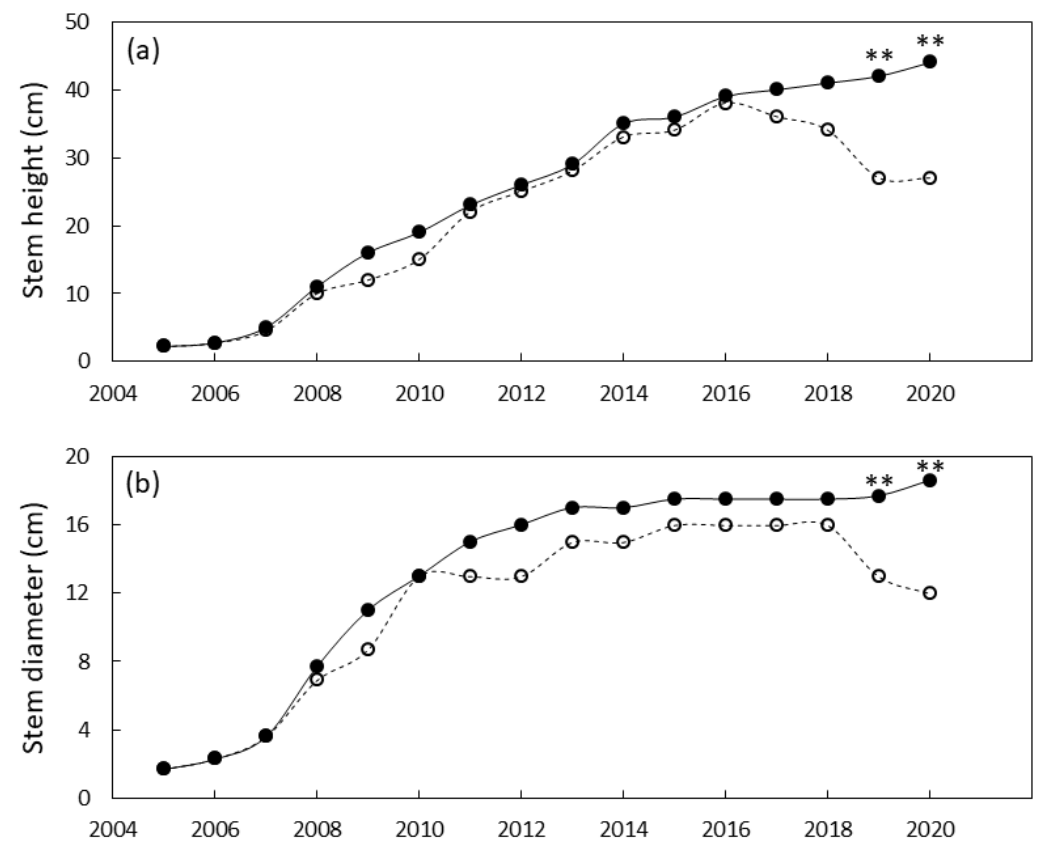

Figure 7. Size of Cycas micronesica plants growing in a north Guam garden over a $15 \mathrm{y}$ growth period. (a) leaf number and (b) maximum leaf length. Closed circles are local genotypes, open circles are foreign genotypes. ${ }^{* *}=$ significant at $p \leq 0.01$.

\section{Discussion}

Plants are sessile and long-distance travel of seeds or pollen is constrained for most species, so local genetic differentiation among plant populations occurs through natural selection. My study adds to a large body of literature that indicates local adaptation of plants is a common phenomenon of plant population traits. My study is the first cycad reciprocal garden study which looked exclusively at natural selection factors, as the only other study I am aware of tested local adaptation to undisturbed versus anthropogenically disturbed 
habitats for Zamia fairchildiana L.D. Gómez [15]. Concerning my primary objective, Guam's C. micronesica population exhibited extreme local adaptation with survival of less than $10 \%$ for foreign genotypes and $70 \%-100 \%$ for local genotypes after $15 \mathrm{y}$. These genetic differences were augmented by habitat quality differences. The south garden site exhibited overall greater quality than the north site for $C$. micronesica growth and survival. The north garden was more hostile to the local genotypes than was the south garden site. Concerning my secondary objective, mortality of the foreign genotypes occurred with similar timing and percentage for the two contrasting gardens. Therefore, neither ecotype exhibited plasticity in adaptation to the environmental conditions of the foreign garden conditions.

Differences in plant size between local and foreign genotypes were much greater beginning about 2018. These size metrics did not decline for the foreign genotypes because individual plants declined in size. The dramatic declines in mean size for the foreign genotypes occurred due to mortality of some of the larger individuals which removed their values from the overall mean.

\subsection{Lessons}

The factors that may have provided a selection gradient in this study were latitudinal gradient, proximity of garden site to source habitat, and highly contrasting edaphic characteristics. The latitudinal gradient was only $45 \mathrm{~km}$, and the observable historical climate of the two source sites and two garden sites is homogeneous. Therefore, rainfall or temperature gradients linked to latitude do not explain the local adaptation differences. The possibility exists that the greater distance between the north source and north garden site than the south source and south garden site explains the superior performance of local genotypes in the south garden. The need for a secured, fenced location for the long-term gardens did not allow the positioning of the north garden site closer to the source habitat.

The most likely source of environmental variation that explained the poor performance of the foreign genotypes in both garden sites involved the edaphic characteristics. These two soils are highly contrasting in physics and chemistry [26]. One pedological factor that exerted historical influence on these contemporary soils is the parent material. The island of Guam was formed through volcanism, and the parent material for most of southern Guam substrates are the ancient volcano surfaces. Extensive reef systems formed in the epipelagic zone surrounding the volcanic formations. This reef system synthesized extensive calcium carbonate formations which were subsequently tectonically uplifted to create the parent material for most northern Guam soils. A second pedological factor responsible for the contrast in Guam's soils is topography. The volcanic parent material experience extensive runoff and erosion processes, but the uplifted reef parent material experienced minimal runoff and erosion. The northern half of Guam is essentially an uplifted plateau and the soils are highly drained, exhibit alkaline $\mathrm{pH}$, and constrain plant growth by reduced availability of several micronutrients due to soil reaction. The south soils are volcanic in origin, poorly drained, exhibit acidic soil reaction, and constrain plant growth by calcium deficiency and aluminum toxicity. Soil microenvironments even on small scales have been shown to elicit adaptive radiation in plants which engenders local adaptation to specific soil microenvironments [31-33].

When local genotypes out-perform foreign genotypes in a reciprocal garden study, the results are typically discussed as evidence of natural selection [34,35]. However, little has been discussed about the potential of separate founder events for insular tree populations. Cycas micronesica belongs to an island species complex, and the members of this complex produce buoyant seeds which employ hydrochory to vector seeds between islands $[17,24]$. The genetic isolation of Guam's north population from the south population [23] may indeed be due to adaptive radiation following a single founder event, but it may also be due to separate founder events which began with bottlenecks of genetic variation that not only differed from the ancestral population but also from each other. My case study illuminates a scenario where local adaptation may not evince natural selection, but may instead evince separate hydrochory founder events. 
This study illuminates the need for long-term vision by conservation funding agencies. Most conservation projects target mitigation efforts rather than research [36] and results are constrained to the few years of the project's timeline. Development of new knowledge during most publicly funded projects stops when the final invoices are paid. The only other reciprocal transplant study for cycads [15] was terminated after 6 months of plant growth in the reciprocal gardens. The two C. micronesica Guam garden sites in my study did not begin to reveal local adaptation until $4-5 \mathrm{y}$ after the gardens were implemented. If this project carried the typical 1-3 y timeline of most publicly funded projects, the results would have erroneously indicated there was no local adaptation. Bennington et al. [37] provided a compelling case study where local adaptation evidence following $13 \mathrm{y}$ of plant growth in reciprocal transplant gardens was considerable, but was minimal when compared with the evidence that was available following $30 \mathrm{y}$ of growth. Most of the conservation projects on Guam use survival of the C. micronesica transplants after 12 months as the metric of success. Reliance on this metric is clearly of no value and wastes taxpayer funds, as most or all of the maladapted transplants will die long after this 12-month timeline. My study reveals how long-term monitoring of restoration sites is required for conservation projects to adequately contribute new knowledge to adaptive management.

The genotype main factor was significant in the ANOVA because south genotypes were more robust than north genotypes. This is easily seen by comparing the vertical axis ranges for the south site (Figures 4 and 5) with those for the north site (Figures 6 and 7). Common garden studies are needed to determine if Guam's south genotypes which evolved in volcanic soils are truly more robust than north genotypes which evolved in coralline soils.

\subsection{Future Research Needs}

The considerable literature on the prevalence of local adaptation in tree species has not sufficiently teased apart all of the influences of ecology, plant life history, and evolution on gene flow that leads to local adaptation. Several avenues of further cycad research have been illuminated by this study.

This study excluded interspecific competition from the gardens by using the commonly employed conspecific monoculture approach for the gardens. However, the extent of exposure to competition from congeneric neighbors may influence the outcomes of reciprocal garden studies [38]. Indeed, C. micronesica plants growing in competition with congeneric tree species exhibited leaf nutrient concentrations that were less than those of plants growing in gardens with only conspecific neighbors [39]. Therefore, more reciprocal transplant studies are needed which include transplantation of entire sympatric plant communities rather than transplantation of the single cycad species. Alternatively, reciprocal transplant approaches which use natural forest environments for the reciprocal experimental sites may provide results with greater ecological integrity [10].

Studying the level of plasticity and adaptation to foreign garden sites also needs to address entire plant-mutualist communities. For cycad restoration sites to be successful, local adaptation of the mycorrhizae, cyanobacteria, and pollinator mutualists may be as important as local adaptation of the cycad species. My study controlled for these relationships by ensuring these mutualists were not transplanted. This approach provided an important first step to begin to build the needed foundation of knowledge. But more complex experimental approaches are needed where entire mutualist communities are reciprocally transplanted, not just the host cycad plant community [40].

Resistance to leaf herbivory among closely positioned subpopulations of Quercus rubra L. were shown to occur through reciprocal garden experiments [41]. The insular populations of $C$. micronesica on the island of Guam are facing risk of extinction due to insect herbivores [19]. However, only one of the leaf or stem consumers is native, and the remainder of the species were very recent invasions to the island. Therefore, disparity in herbivory from co-evolved herbivores among various habitats could not explain the differences in north versus south Guam habitats. The two most threatening invasive 
species are A. yasumatsui and L. pandava, and both of these insects have also invaded the adjacent island of Rota [19]. The native insect herbivore that is among the acute threats to Guam's C. micronesica population is the stem borer Acalolepta marianarum Aurivillius [42]. As with most bark or stem borers, this beetle oviposits in stems of stressed host trees, so damage to Guam's C. micronesica trees increased dramatically after the damage that was caused by the invasions of the non-native insects [43]. The C. micronesica trees on Rota have not experienced damage from the native stem borer, setting up an interesting opportunity to use reciprocal gardens to determine if the Rota populations are less resistant to $A$. marianarum herbivory than are the Guam populations.

My pilot cycad study used half-siblings for both genotypes in both gardens in order to control for genetic variation with each source habitat. However, the level of genetic diversity within each source habitat may influence outcomes of reciprocal garden studies. Therefore, more studies are required which include multiple genotypes within each source habitat to determine the level of plasticity as influenced by intra-habitat variation in genotype.

\subsection{Conservation Applications}

Botanic gardens with extensive species collections composed of genotypes from many ecological or geographic zones may be ideally positioned to observe plant performance and longevity as a common garden experiment. The common garden experimental approach allows the comparison of genetically distinct subpopulations of a single species while growing in homogeneous environmental conditions, and is sometimes called a provenance test. Botanic garden collections exhibit considerable attrition over time [44,45], and germplasm curators may be able to correlate attrition rates with each genetically distinct subpopulation. My study indicates that a focus on soil physical and chemical characteristics could provide the foundation of long-term observational studies designed to determine if cycad genotypes from native habitats with soils most similar to those of the botanic garden exhibit greater growth and survival over time than the genotypes from habitats with soils dissimilar to those of the botanic garden.

Thousands of $C$. micronesica trees have been and continue to be removed from military installations on Guam prior to clearing of the forests to enable ongoing construction activities $[16,46]$. Some of these rescued trees have been transplanted to remote restoration sites for the purpose of conserving the genes from the construction sites. Reintroductions and restoration sites may be at risk of failure even if small gaps in knowledge exist [6]. These Guam restoration sites will not be successful if knowledgeable cycad biologists are excluded from the decision-making teams [47,48], because appropriate expertise will not be available for matching the plant genotypes with the appropriate restoration sites. For example, the primary restoration site on Guam for recently transplanted C. micronesica trees is a highly disturbed site where the non-native Vitex parviflora Juss. occupies the emergent canopy. This invasive tree alters soil chemistry to produce subtending soils that are in sharp contrast to the soils with native tree cover [49]. The only previously published reciprocal transplant study for cycads revealed that a disturbed habitat only $20 \mathrm{~km}$ from an undisturbed habitat exhibited local adaptation of the cycad population [15]. Therefore, the decision to use of the disturbed $V$. parviflora habitat for the $C$. micronesica restoration project was contrary to the best available science to inform best management practices. The choice of this restoration site was contrary to the Integrated Natural Resource Management Plan that was published to guide the decisions [50], which mandates the use of best management practices. The transplanted trees will likely be maladapted to the disturbed site and the transplantation projects are at risk of ending in failure.

The ongoing costly transplantation projects on Guam also ignore the primary threats to species survival. The primary threats that are propelling this arborescent cycad species toward extinction are ubiquitous non-native insect herbivores [19]. Until available conservation funds are re-directed toward mitigation of these primary threats, no amount of continued expenditures for transplantation projects will be of value for species recovery [51]. 


\section{Conclusions}

The first reciprocal garden approach designed to determine the level of natural selection of a cycad species revealed acute local adaptation of $C$. micronesica plants from the island of Guam. The likely selection factor which generated local adaptation was the extreme contrast in edaphic characteristics for the two reciprocal sites. The study provides an example of how experimental approaches can engender progress toward understanding the population differences to improve conservation decision-making. The results also reveal how short-term grants and contracts may generate inaccurate results during the traditional 1-3 y timeline. The findings may be used to explain observed disparity in attrition rates for germplasm collections in botanic gardens where a species collection is comprised of many provenances. Observational studies from these germplasm collections may demonstrate that genotypes from localities with edaphic characteristics most similar to those of the botanic garden may perform better in the common garden setting. This study also provided crucial initial findings that indicate conservation decision-makers must include the issue of local adaptation when selecting germplasm and restoration sites for reintroductions or transplantation projects.

Funding: This research was funded in part by the United States Forest Service grant numbers 06-DG-11052021-206, 09-DG-11052021-173, 13-DG-11052021-210, and 17-DG-11052021-217.

Institutional Review Board Statement: Not applicable.

Informed Consent Statement: Not applicable.

Data Availability Statement: Data in this study are available on request.

Acknowledgments: I thank Gil Cruz, Nirmala Dongol, and Frankie Matanane for technical support for construction and maintenance of the gardens.

Conflicts of Interest: The author declares no conflict of interest. The funders had no role in the design of the study; in the collection, analyses, or interpretation of data; in the writing of the manuscript, or in the decision to publish the results.

\section{References}

1. Mounce, R.; Smith, P.; Brockington, S. Ex situ conservation of plant diversity in the world's botanic gardens. Nat. Plants 2017, 3, 795-802. [CrossRef]

2. Werden, L.K.; Sugii, N.C.; Weisenberger, L.; Keir, M.J.; Koob, G.; Zahawi, R.A. Ex situ conservation of threatened plant species in island biodiversity hotspots: A case study from Hawai'i. Biol. Conserv. 2020, 243, 108435. [CrossRef]

3. Westwood, M.; Cavender, N.; Meyer, A.; Smith, P. Botanic garden solutions to the plant extinction crisis. Plants People Planet 2020, 3, 22-32. [CrossRef]

4. Viani, R.A.G.; Barreto, T.E.; Farah, F.T.; Rodrigues, R.R.; Brancalion, P.H.S. Monitoring young tropical forest restoration sites: How much to measure? Trop. Conserv. Sci. 2018, 11, 1-9. [CrossRef]

5. Volis, S. Conservation-oriented restoration-A two for one method to restore both threatened species and their habitats. Plant Divers. 2019, 41, 50-58. [CrossRef]

6. Abeli, T.; Dixon, K. Translocation ecology: The role of ecological sciences in plant translocation. Plant Ecol. 2016, 217, 123-125. [CrossRef]

7. Marler, T.E. Conservation of local genotypes when planting native plants on Guam. Micrones. Suppl. 2002, 6, 55-60.

8. Broadhurst, L.M.; Lowe, A.; Coates, D.J.; Cunningham, S.A.; McDonald, M.; Vesk, P.A.; Yates, C. Seed supply for broadscale restoration: Maximizing evolutionary potential. Evol. Appl. 2008, 1, 587-597. [CrossRef]

9. Johnson, L.C.; Olsen, J.T.; Tetreault, H.; DeLaCruz, A.; Bryant, J.; Morgan, T.J.; Knapp, M.; Bello, N.M.; Baer, S.G.; Maricle, B.R. Intraspecific variation of a dominant grass and local adaptation in reciprocal garden communities along a US Great Plains' precipitation gradient: Implications for grassland restoration with climate change. Evol. Appl. 2015, 8, 705-723. [CrossRef] [PubMed]

10. Nuismer, S.L.; Gandon, S. Moving beyond common-garden and transplant designs: Insight into the causes of local adaptation in species interactions. Amer. Nat. 2008, 171, 658-668. [CrossRef] [PubMed]

11. Ågren, J.; Schemske, D.W. Reciprocal transplants demonstrate strong adaptive differentiation of the model organism Arabidopsis thaliana in its native range. New Phytol. 2012, 194, 1112-1122. [CrossRef]

12. Fragniere, Y.; Bétrisey, S.; Cardinaux, L.; Stoffel, M.; Kozlowski, G. Fighting their last stand? A global analysis of the distribution and conservation status of gymnosperms. J. Biogeogr. 2015, 42, 809-820. [CrossRef]

13. Marler, P.N.; Marler, T.E. An assessment of Red List data for the Cycadales. Trop. Conserv. Sci. 2015, 8, 1114-1125. [CrossRef] 
14. Calonje, M.; Stevenson, D.W.; Osborne, R. The World List of Cycads, Online Edition. 2013-2021. Available online: http://www. cycadlist.org (accessed on 29 May 2021).

15. Lopez-Gallego, C. Genotype-by-environment interactions for seedling establishment across native and degraded-forest habitats in a long-lived cycad. Bot. Rev. 2013, 79, 542-558. [CrossRef]

16. Deloso, B.E.; Ferreras, U.F.; Marler, T.E. Does phytogeography change with shifts in geopolitics? The curious case of cycads in the United States. Diversity 2020, 12, 445. [CrossRef]

17. Hill, K.D. The Cycas rumphii complex (Cycadaceae) in New Guinea and the western Pacific. Aust. Syst. Bot. 1994, 7, 543-567. [CrossRef]

18. Donnegan, J.A.; Butler, S.L.; Grabowiecki, W.; Hiserote, B.A.; Limtiaco, D. Guam's Forest Resources, 2002. Resource Bulletin PNW-RB-243; U.S. Department of Agriculture, Forest Service, Pacific Northwest Research Station: Portland, OR, USA, 2004.

19. Deloso, B.E.; Terry, L.I.; Yudin, L.S.; Marler, T.E. Biotic threats to Cycas micronesica continue to expand to complicate conservation decisions. Insects 2020, 11, 888. [CrossRef] [PubMed]

20. Marler, T.E.; Krishnapillai, M.V. Longitude, forest fragmentation, and plant size influence Cycas micronesica mortality following island insect invasions. Diversity 2020, 12, 194. [CrossRef]

21. Marler, T.; Haynes, J.; Lindstrom, A. Cycas micronesica. The IUCN Red List of Threatened Species; E.T61316A12462113. IUCN Global Species Programme; Cambridge, UK, 2010; Available online: https:/ / dx.doi.org/10.2305/IUCN.UK.2010-3.RLTS.T61316A12462 113.en (accessed on 29 May 2021).

22. United States Fish \& Wildlife Service. Endangered and threatened wildlife and plants; endangered status for 16 species and threatened status for 7 species in Micronesia. Fed. Regist. 2015, 80, 59424-59497.

23. Cibrian-Jaramillo, A.; Daly, A.C.; Brenner, E.; DeSalle, R.; Marler, T.E. When North and South don't mix: Genetic connectivity of a recently endangered oceanic cycad, Cycas micronesica, in Guam using EST-microsatellites. Mol. Ecol. 2010, 19, $2364-2379$. [CrossRef]

24. Norstog, K.J.; Nicholls, T.J. The Biology of the Cycads; Cornell Univ. Press: Ithaca, NY, USA, 1997; ISBN 978-0-8014-3033-6.

25. Santini, G.; Biondi, N.; Rodolfi, L.; Tredici, M.R. Plant biostimulants from cyanobacteria: An emerging strategy to improve yields and sustainability in agriculture. Plants 2021, 10, 643. [CrossRef]

26. Young, F.J. Soil Survey of Territory of Guam; U. S. Dept. of Agric. Soil Conservation Service: Washington, DC, USA, 1988.

27. Olsen, S.R.; Cole, C.V.; Watanabe, F.S.; Dean, L.A. Estimation of Available Phosphorus in Soils by Extraction with Sodium Bicarbonate; U.S. Dept. of Agric. Circ.: Washington, DC, USA, 1954; p. 939.

28. Hue, N.V.; Ikawa, H.; Huang, X. Predicting soil phosphorus requirements. In Plant Nutrient Management in Hawaii's Soils, Approaches for Tropical and Subtropical Agriculture; Silva, J.A., Uchida, R., Eds.; College of Tropical Agriculture and Human Resources, University of Hawaii at Manoa: Honolulu, HI, USA, 2000; pp. 95-99.

29. Berghage, R.D.; Krauskopf, D.M.; Warncke, D.D.; Widders, I. Micronutrient Testing of Plant Growth Media Extractant, Identification and Evaluation. Commun. Soil Sci. Plant Anal. 1987, 18, 1089-1109. [CrossRef]

30. Mann, H.B.; Whitney, D.R. On a test of whether one of two random variables is stochastically larger than the other. Ann. Math. Stat. 1947, 18, 50-60. [CrossRef]

31. Joshi, J.; Schmid, B.; Caldeira, M.C.; Dimitrakopoulos, P.G.; Good, J.; Harris, R.; Hector, A.; Huss-Danell, K.; Jumpponen, A.; Minns, A.; et al. Local adaptation enhances performance of common plant species. Ecol. Lett. 2001, 4, 536-544. [CrossRef]

32. Baltzer, J.L.; Thomas, S.C.; Nilus, R.; Burslem, D.F.R.P. Edaphic specialization in tropical trees: Physiological correlates and responses to reciprocal transplantation. Ecology 2005, 86, 3063-3077. [CrossRef]

33. Ellis, A.G.; Weis, A.E. Coexistence and differentiation of 'flowering stones': The role of local adaptation to soil microenvironment. J. Ecol. 2006, 94, 322-335. [CrossRef]

34. Nagy, E.S.; Rice, K.J. Local adaptation in two subspecies of an annual plant: Implications for migration and gene flow. Evolution 1997, 51, 1079-1089. [CrossRef]

35. Kawecki, T.J.; Ebert, D. Conceptual issues in local adaptation. Ecol. Lett. 2004, 7, 1225-1241. [CrossRef]

36. Marler, T.E.; Lindström, A.J. The value of research to selling the conservation of threatened species: The case of Cycas micronesica. J. Threat. Taxa 2014, 6, 6523-6528. [CrossRef]

37. Bennington, C.; Fetcher, N.; Vavrek, M.; Shaver, G.; Cummings, K.; McGraw, J. Home site advantage in two long-lived arctic plant species: Results from two 30-year reciprocal transplant studies. J. Ecol. 2012, 100, 841-851. [CrossRef]

38. Schoen, D.J.; Stewart, S.C.; Lechowicz, M.J.; Bell, G. Partitioning the transplant site effect in reciprocal transplant experiments with Impatiens capensis and Impatiens pallida. Oecologia 1986, 70, 149-154. [CrossRef]

39. Deloso, B.E.; Krishnapillai, M.V.; Ferreras, U.F.; Lindström, A.J.; Calonje, M.; Marler, T.E. Chemical element concentrations of cycad leaves: Do we know enough? Horticulturae 2020, 6, 85. [CrossRef]

40. Miglia, K.; McArthur, E.; Redman, R.; Rodriguez, R.; Zak, J.; Freeman, D. Genotype, soil type, and locale effects on reciprocal transplant vigor, endophyte growth, and microbial functional diversity of a narrow sagebrush hybrid zone in Salt Creek Canyon, Utah. Amer. J. Bot. 2007, 94, 425-436. [CrossRef] [PubMed]

41. Sork, V.L.; Stowe, K.A.; Hochwender, C. Evidence for local adaptation in closely adjacent subpopulations of Northern Red Oak (Quercus rubra L.) expressed as resistance to leaf herbivores. Amer. Nat. 1993, 142, 928-936. [CrossRef]

42. Marler, T.E.; Muniappan, R. Pests of Cycas micronesica leaf, stem, and male reproductive tissues with notes on current threat status. Micronesica 2006, 39, 1-9. 
43. Marler, T.E. Temporal variations in leaf miner, butterfly, and stem borer infestations of Cycas micronesica in relation to Aulacaspis yasumatsui incidence. HortScience 2013, 48, 1334-1338. [CrossRef]

44. Griffith, M.P.; Barber, G.; Tucker Lima, J.; Barros, M.; Calonje, C.; Noblick, L.R.; Calonje, M.; Magellan, T.; Dosmann, M.; Thibault, T.; et al. Plant collection "half-life:" can botanic gardens weather the climate? Curator Mus. J. 2017, 60, 395-410. [CrossRef]

45. Hoban, S. New guidance for ex situ gene conservation: Sampling realistic population systems and accounting for collection attrition. Biol. Conserv. 2019, 235, 199-208. [CrossRef]

46. Marler, T.E.; Calonje, M. Stem branching of cycad plants informs horticulture and conservation decisions. Horticulturae 2020, 6, 65. [CrossRef]

47. Marler, T.E.; Griffith, M.P.; Krishnapillai, M.V. Height increment of Cycas micronesica informs conservation decisions. Plant Signal. Behav. 2020, 15, e1830237. [CrossRef] [PubMed]

48. Marler, T.E.; Matanane, F.C.; Terry, L.I. Burrowing activity of coconut rhinoceros beetle on Guam cycads. Commun. Integr. Biol. 2020, 13, 74-83. [CrossRef] [PubMed]

49. Marler, T.E. Three invasive tree species change soil chemistry in Guam forests. Forests 2020, 11, 279. [CrossRef]

50. Joint Region Marianas. Final Integrated Natural Resources Management Plan Joint Region Marianas-Guam, Tinian, and Farallon de Medinilla; Prepared under Contract \#SF1449-N40192-10-R-9915; NAVFAC Marianas: Piti, Guam, 2012.

51. Marler, T.E.; Lindström, A.J. First, do no harm. Commun. Integr. Biol. 2017, 10, e1393593. [CrossRef] [PubMed] 